\title{
Immune response of mice to non-adapted avian influenza A virus
}

\author{
A. STROPKOVSKÁ ${ }^{1,2}$, T. MIKUŠKOVÁ ${ }^{1}$, Z. BOBIŠOVÁ ${ }^{1}$, I. KOŠÍK ${ }^{1}$, V. MUCHA ${ }^{1}$, F. KOSTOLANSKÝ ${ }^{1}$, \\ E. VAREČKOVÁ ${ }^{1^{*}}$
}

${ }^{1}$ Institute of Virology, Slovak Academy of Sciences, 84505 Bratislava, Slovak Republic; ${ }^{2}$ Institute of Neurobiology, Slovak Academy of Sciences, Šoltésovej 4-6, 04001 Košice, Slovak Republic

Received July 7, 2015; accepted August 24, 2015

\begin{abstract}
Summary. - Human infections with avian influenza A viruses (IAVs) without or with clinical symptoms of disease were recently reported from several continents, mainly in high risk groups of people, who came into the contact with infected domestic birds or poultry. It was shown that avian IAVs are able to infect humans directly without previous adaptation, however, their ability to replicate and to cause a disease in this new host can differ. No spread of these avian IAVs among humans has been documented until now, except for one case described in Netherlands in the February of 2003 in people directly involved in handling IAV (H7N7)-infected poultry. The aim of our work was to examine whether a low pathogenic avian IAV can induce a virus-specific immune response of biological relevancy, in spite of its restricted replication in mammals. As a model we used a low pathogenic virus A/Duck/Czechoslovakia/1956 (H4N6) (A/Duck), which replicated well in MDCK cells and produced plaques on cell monolayers, but was unable to replicate productively in mouse lungs. We examined how the immune system of mice responds to the intranasal application of this non-adapted avian virus. Though we did not prove the infectious virus in lungs of mice following A/Duck application even after its multiple passaging in mice, we detected virus-specific vRNA till day 8 post infection. Moreover, we detected virus-specific mRNA and de novo synthesized viral nucleoprotein (NP) and membrane protein (M1) in lungs of mice on day 2 and 4 after exposure to A/Duck. Virus-specific antibodies in sera of these mice were detectable by ELISA already after a single intranasal dose of A/Duck virus. Not only antibodies specific to the surface glycoprotein hemagglutinin (HA) were induced, but also antibodies specific to the NP and M1 of IAV were detected by Western blot and their titers increased after the second exposure of mice to this virus. Importantly, antibodies neutralizing virus A/Duck were proved in mouse immune sera after the second dose of virus and a slight increase of mRNA expression of immune mediators tumor necrosis factor alpha (TNF- $\alpha$ ) and IP10 has been observed in lungs of these mice $48 \mathrm{hr}$ after the infection. These observations correspond to the limited replication ability of the virus in mice and provided an important information about its ability to induce virusspecific antibodies, including those neutralizing virus, even without the previous virus adaptation to the new mammalian host. Such antibodies could consequently influence the immune potential of exposed individuals and their defensive capability against the newly emerged, even more virulent IAV.
\end{abstract}

Keywords: avian influenza A virus; virus-neutralizing antibodies; cytokine expression; virus replication in mice; viral protein synthesis

*Corresponding author. E-mail: viruevar@savba.sk; phone: +421$2-59302427$.

Abbreviations: A/Duck = A/Duck/Czechoslovakia/1956 (H4N6); A/Miss = A/Mississippi/1/1985 (H3N2); HA = hemagglutinin; $\operatorname{IAV}(\mathrm{s})=$ influenza A virus(es); IL-1, -6, -13 = interleukin 1, 6, $13 ; \mathrm{M} 1=$ membrane protein $1 ; \mathrm{MAb}=$ monoclonal antibody; $\mathrm{NP}=$ nucleoprotein; $\mathrm{RCA}=$ rapid culture assay; $\mathrm{TCID}=$ tissue culture infection dose; TNF- $\alpha=$ tumor necrosis factor alpha; $\mathrm{VN}=$ virus-neutralizing

\section{Introduction}

Influenza A viruses (IAVs) repeatedly cause epidemic respiratory disease in humans. The reason is the high variability of IAVs and a wide host range, enabling the adaptation of avian IAV to mammals and consequently resulting in the ability to infect them. The reservoir of potentially new emerging IAVs invading human population is considered to 
be the wild waterfowl. Sporadic cases of human infections caused by avian IAVs have been described since the year 1997, but the spread of these viruses among humans has not yet been unambiguously documented (Subbarao et al., 1998; Subbarao and Katz, 2000; Liu et al., 2003; Li et al., 2004; Wong et al., 2006; Neumann et al., 2010, Driskell et al., 2012; Liu et al., 2014), except one evidence in Netherlands in 2003 (Koopmans et al., 2004, DuRy et al., 2005).

It is known that avian IAVs have a varying ability to replicate in mammals. Some of them acquire the replication capacity in mammals during the adaptation process and cause lethal pneumonia in this new host, others replicate in lungs of infected individuals without clinical symptoms or do not replicate at all (Karasin et al., 2000; Peiris et al., 2001; Joseph et al., 2007; Kang et al., 2013; Klenk et al., 2013). The replication potential of avian viruses in mammals is conditioned by many viral factors cooperating together, like receptor-binding specifity, changes in glycosylation sites on the HA molecule, heat and pH stability of HA, length of the neuraminidase (NA) stalk, properties of RNA-polymerase activity related to changes in the subunits of RNA-polymerase complex, mainly the PB2 protein (Resa-Infante and Gabriel, 2012; Košík et al., 2013; Resa-Infante et al., 2014; Schrauwen and Fouchier, 2014; Neumann and Kawaoka, 2015). But also the host-cell factors and the immune response of the new host play an important role in the process of virus adaptation and transmissibility from birds to humans (Korth et al., 2006; Weber and Stilianakis, 2007; Fislová et al., 2010; Konig et al., 2010; Tscherne and Garcia-Sastre, 2011). In general, avian IAVs of various subtypes have a potential for adaptation to mammals with yet unknown health risk for humans (Friedl et al., 2014). To better understand the zoonotic potential of circulating avian viruses, we examined whether an avian IAV of H4N6 subtype can induce specific antibody response in mammals without its previous adaptation and replication ability in the new host. For these studies we used a mouse model. Mice were infected with non-pathogenic IAV virus isolated from ducks in Czechoslovakia in the year 1956. We showed that regardless of the inability of this virus to replicate in mouse lungs, it is able to induce specific virus-neutralizing (VN) antibodies in sera of mice exposed to A/Duck IAV and to alter the expression of some cytokines.

\section{Material and Methods}

Viruses. Avian influenza virusA/Duck/Czechoslovakia/1956 (H4N6) (A/Duck) isolated from wild ducks in Czechoslovakia and human virus A/Mississippi/1/85 (H3N2) (A/Miss) originated from the collection of viruses at the Institute of Virology, Slovak Academy of Sciences, Bratislava, Slovak Republic. Viruses were propagated in embryonated chicken eggs as usually (Janulíková et al., 2015).
Detection of viral RNA in mouse lungs. The total RNA was isolated from lung cell homogenate using RNA Instapur ${ }^{\mathrm{TM}}$ System (Eurogentec). Viral RNA (vRNA) was detected by RT-PCR according to Varečková et al. (2006). For reverse transcription of isolated total RNA, the random heptamer (Invitrogen) was used as a primer, and virus-specific vRNA was amplified using virus-specific primers based on sequences obtained from The Influenza Database of Los Alamos National Laboratory using software Primer3 (SAS EMBnet node, EMBnet Slovakia, url: http://embnet.sk/) or VectorNTI 2.0. Following primers were used: External primers for NP type A of human viruses of H3 subtype (509 bp product): FW: 5'-GTGAGGATGCAACAGC TGGTCTAAC-3';REV:5'-TACCCCTCTTTTTCGAAGTCGTAC-3'; internal primers for NP type A of human viruses of $\mathrm{H} 3$ subtype (248 bp product): FW: 5'-CAACGATCGAAATTTCTGGAGAGG-3'; REV: 5'-CAGGTCCATACACACAGGCAGGTA-3'. Primers for H4 HA of IAV were designed based on the sequence analysis of influenza A HA of H4 subtype using software Primer3. Sequence of these primers was following: FW: 5'-ATTCGAATTCATTGCCGAAG-3'; REV: 5'-TCCCCAGATGTAAAGCCTTG-3'. The size of the PCR product was $196 \mathrm{bp}$. PCR products were visualized after their separation by electrophoresis (at 110V, $20 \mathrm{~min}$ ) in $2 \%$ agarose gel containing ethidium bromide.

Detection of virus-specific mRNA in lungs of infected mice. For mRNA detection the same conditions were used as above, except oligo (dT) primer was used for reverse transcription instead of random heptamer. Lungs of mice, to which the UV-inactivated viruses A/Duck or A/Miss were applied, were used as negative controls.

Real-time PCR. The quantification of cytokine mRNA expression was performed by the method of real-time PCR using DyNAmo ${ }^{\mathrm{TM}}$ HS SYBR ${ }^{\circ}$ Green qPCR Kit (Finnzymes) and the thermocycler Quantica (Techne, UK). The total RNA was isolated from lung cell homogenate using RNA Instapur ${ }^{\mathrm{TM}}$ System (Eurogentec) and cDNA was obtained by reverse transcription as described above. The cDNA corresponding to mRNA of examined cytokines was amplified using cytokine-specific primers. Specific primers for mouse cytokines and $\beta$-actin were designed using the program Primer3:

TNF-a: FW: 5'-GCCGATTTGCTATCTCATAC-3'; REV: 5'TGGGTAGAGAATGGATGAAC-3'; IL-1: FW: 5'-AGAACCTC TGAAACGTCAAA-3'; REV: 5'-ATGACAAACTTCTGCCTGAC-3'; IL-6: FW: 5'-ACAAGAAAGACAAAGCCAGA-3'; REV: 5'-TTA GGCATAACGCACTAGGT-3'; IL-13: FW: 5'-ATCACACAAGA CCAGACTCC-3'; REV: 5'-CAGTTGCTTTGTGTAGCTGA-3'; IP-10: FW: 5'-GACAATAACTGCACCCACTT-3'; REV: 5'-TCAAA TGCTCCTTGATTTCT-3';

ß-actin: FW: 5'-AGGTCATCACTATTGGCAAC-3'; REV: 5'ATCTTGATCTTCATGGTGCT-3'. Ten-fold-dilutions of $\beta$-actin cDNA ranging from $4 \times 10^{-3}$ to $4 \times 10^{-8} \mathrm{ng} / \mu \mathrm{l}$ were used as standards for quantification of cytokine mRNA expression.

Determination of the level of cytokines by ELISA. The amount of cytokines in lung cell suspension was determined by immuno-capture ELISA kit Ready-SET-GO (Bioscience) according to manufacturer's instructions. Briefly: Cytokines were captured from lung cell suspension via particular mouse cytokine-specific immuno-capture antibody 
bound to the solid phase of 96-well micro-titration plate. Examined cytokines were detected after overnight incubation at $+4^{\circ} \mathrm{C}$. The biotinconjugated detector antibody specific for each cytokine was added to the reaction mixture and subsequently incubated with horseradish peroxidase-conjugated avidin. Then, after a period of $30 \mathrm{~min}$, the substrate tetramethylbenzidine with hydrogen peroxide was added. The reaction was stopped with $1 \mathrm{M} \mathrm{H}_{2} \mathrm{SO}_{4}$ and the color reaction was evaluated by measuring the absorbance at 450 and $570 \mathrm{~nm}$ on ELISA reader Multiscan MCC/340 (Labsystem). The concentrations of cytokines in the particular samples $(\mathrm{pg} / 100 \mu \mathrm{l})$ were calculated from the calibration curve according to the manufacturer's instructions.

Western blot analysis of antibodies in mouse immune sera. Proteins of purified virus A/Duck $(2 \mathrm{mg} / \mathrm{ml}$ ) were separated by $12 \%$ SDS-PAGE under nonreducing conditions and electroblotted onto nitrocellulose membrane (Hybond-C Extra; Amersham Biosciences) in $10 \mathrm{mmol} / \mathrm{l}$ Tris/glycine buffer as described previously (Gocník et al., 2008). Nitrocellulose strips with the blotted proteins were incubated individually with twofold dilutions of the immune serum in PBS containing 3\% non-fat dry milk for $2 \mathrm{hr}$ at room temperature and washed with $0.01 \%$ Triton X-100 in PBS. Bound antibodies were detected with horseradish peroxidase-conjugated goat anti-mouse IgG (in 3\% non-fat dry milk for $1 \mathrm{~h}$ at room temperature) by adding the substrate diaminobenzidine tetrahydrochloride with $0.03 \% \mathrm{H}_{2} \mathrm{O}_{2}$. After color development, the reaction was stopped by washing the strips with $\mathrm{H}_{2} \mathrm{O}$, and the titers of antibodies in sera were evaluated as the reciprocal value of the highest dilution of serum, in which a band of appropriate molecular mass was still detected. To identify the position of HA, NP and M1 proteins on the nitrocellulose membrane, molecular mass standards were used and a control immunochemical detection was carried out using monoclonal antibody (MAb) IIF4 specific for HA, cross-reactive with H4 virus (Stropkovská et al., 2009), MAb 107L specific for the NP and MAb 290/3 specific for M1 protein of IAVs (Varečková et al., 1995).

Indirect immunofluorescence. Viral proteins (M1, NP) were detected in lungs of mice challenged with $\mathrm{A} / \mathrm{Duck}$ virus by indirect immunofluorescence. Lungs were collected at day 2 or 4 after the infection ( 2 mice per group), washed with PBS and digested for $30 \mathrm{~min}$ at $37^{\circ} \mathrm{C}$ in RPMI medium containing collagenase $(2 \mathrm{mg} /$ $\mathrm{ml})$. The single cell suspensions from lungs were prepared using $70 \mu \mathrm{m}$ cell strainers (Falcon) and lung cells were transferred onto 24-well plates precoated with concanavalin A (Sigma). Plates were incubated at $37^{\circ} \mathrm{C}$ in $5 \% \mathrm{CO}_{2}$ in DMEM medium containing $5 \%$ fetal bovine serum. After $30 \mathrm{~min}$, cells were fixed with $2 \%$ paraformaldehyde (Sigma) in PBS for $10 \mathrm{~min}$ and permeabilized with 1\% Triton X-100 (Koch-Light) for $60 \mathrm{sec}$. Samples were then washed three times with PBS and incubated for $1 \mathrm{hr}$ at $25^{\circ} \mathrm{C}$ with MAb 107L for IAV NP $(1.5 \mu \mathrm{g} / \mathrm{ml})$ and MAb 290/3 for membrane protein M1 (Varečková et al., 1995). Washing step was repeated and cells were incubated for $1 \mathrm{~h}$ with the second antibody, FITC-conjugated antimouse IgG (Dako). After the final wash, the samples were mounted with DAPI (4',6-diamino-2-phenylindole)-containing mounting medium (Santa Cruz Biotechnologies). Fluorescence was evaluated using fluorescence microscope (Leica CTR 600).
Plaque assay. Virus was titrated by a standard plaque assay as described before (Varečková et al., 2003).

Virus-neutralization microassay. The VN ability of specific antibodies present in sera of mice exposed to A/Duck virus was evaluated by modified rapid culture assay (RCA) according to the protocol described before (Janulíková et al., 2015), using $8 \mathrm{TCID}_{50}$ of A/Duck virus and horseradish peroxidase conjugate of monoclonal antibody specific to NP of IAV (107L-Px) (Tkáčová and Varečková, 1996).

Purified viruses. Virus A/Duck was purified from infectious allantoic fluid by differential and sucrose gradient centrifugations as described previously (Russ et al., 1976).

Preparation of mouse-adapted IAVs. Human virus A/Miss was adapted to mice as described before (Fislová et al., 2009). Avian influenza virus A/Duck could not be adapted to mice (Janulíková et al., 2015). A non-mouse-adapted A/Duck virus was therefore used in all experiments.

Animal experiments. Six-week-old female BALB/c mice (Faculty of Medicine, Masaryk University, Brno, Czech Republic) were used for infection. Mice were infected intranasally under a light narcosis with an appropriate dose of influenza virus (as marked) in a volume $40 \mu \mathrm{l} /$ mouse.

Sera collection. Blood was obtained from the facial vein of mice before and 21 days after each application of virus and serum was prepared by standardly used protocol.

Ethic statement. All animal experiments were performed according to the European Union standards and fundamental ethical principles including animal welfare requirements were respected.

Experiments with avian influenza viruses were conducted under BSL-3 containment, including work with animals.

\section{Results}

Our main goal was to elucidate whether the exposure of mice to non-adapted avian IAVs with limited replication in their lungs results in induction of neutralizing antibodies specific to this avian IAV.

We examined the replication activity of IAV virus A/Duck in mouse lungs and the spectrum of antibodies specific to particular virus proteins, including the $\mathrm{VN}$ ones. We further monitored the cytokine expression and their levels triggered after the inatranasal challenge with infectious virus A/Duck and compared them with the expression after the exposure to UV-inactivated A/Duck or the fully replicating human mouse-adapted A/Miss virus.

\section{Biological characterization of avian IAV A/Duck}

\section{Detection of infectious virus and $v R N A$ in lungs of infected mice}

Virus A/Duck is a low-pathogenic virus isolated from ducks. It multiplied well in vitro on MDCK cells and in the allantoic fluid of fertilized chicken eggs. This virus also 


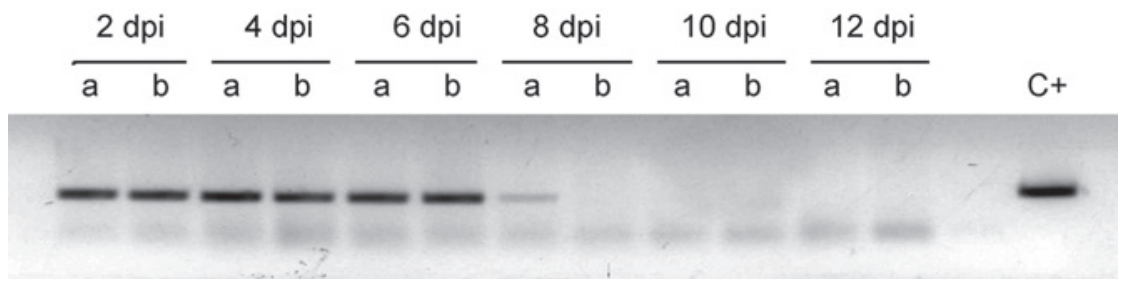

Fig. 1

Kinetics of vRNA presence in lungs of mice infected with A/Duck virus by RT-PCR

vRNA was detected in two mice $(\mathrm{a}, \mathrm{b}) . \mathrm{C}+$ means the $\beta$-actin internal control. Lung samples were collected at several time points $($ days post infection $=\mathrm{dpi})$ as indicated.
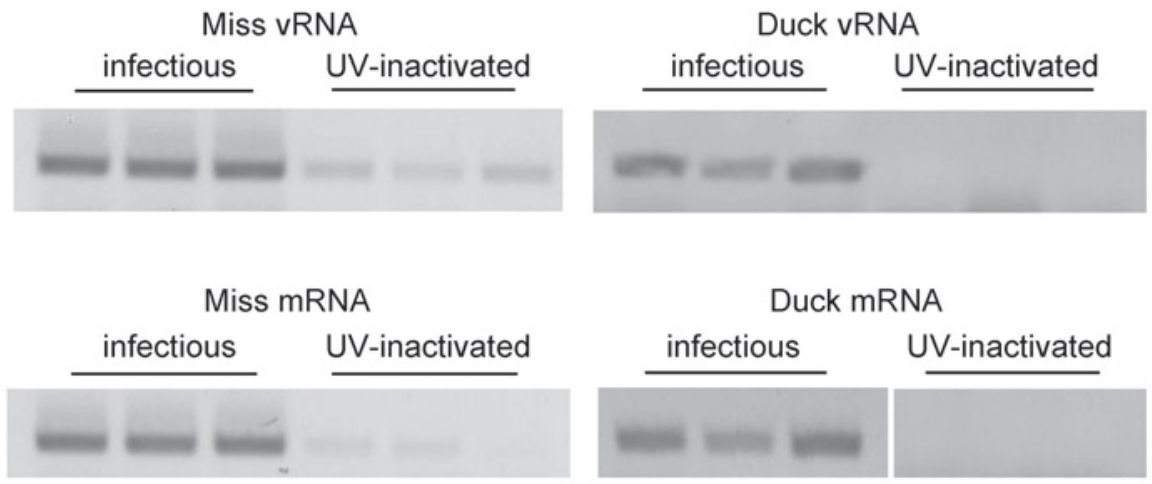

Fig. 2

Detection of mRNA and genomic vRNA in mouse lungs

mRNA in mouse lungs was analyzed $48 \mathrm{hr}$ after intranasal infection with sublethal dose of A/Duck or A/Miss virus or, as a control, with an UV-inactivated A/Duck or A/Miss ( $\mathrm{n}=3$ /each group).

formed countable plaques in the standard plaque assay (Stropkovská et al., 2009). However, when we attempted to adapt $\mathrm{A} / \mathrm{Duck}$ virus to mice by passaging in mouse lungs, no clinical symptoms of disease were visible and no infectious virus was obtained after multiple passaging.

We monitored the presence of the virus in mouse lungs after intranasal application of various infectious doses of nonadapted virus A/Duck ( $\mathrm{n}=3$ mice/group), including relatively high doses of virus: $640,64,6.4$, or $0.64 \mathrm{PFU} /$ mouse. Lungs were collected at different time-points after the infection, starting on day 2. As estimated by RCA, measurable level of infectious virus (titer 100) was present only in lungs of mice infected with two highest doses, 640 and $64 \mathrm{PFU}$, on the second day after the infection. In all other lung samples no infectious virus (RCA titer $<50$ ) was detectable. Viral RNA, however, was present in lungs of mice till 8th day post infection after each dose of non-adapted A/Duck virus (Fig. 1). Moreover, we proved viral mRNA in lungs of infected mice, which indicates the start of vRNA replication (Fig. 2). In contrast, no vRNA or mRNA was detected in lungs of mice in the negative control groups, to which UV-inactivated virus was applied. A group of mice infected with fully replicating virus A/Miss was used as a positive control.

\section{Detection of viral protein synthesis}

Based on above results the question arose whether de novo synthesis of viral proteins could start after the intranasal application of infectious non-adapted A/Duck virus to mice. Using indirect immunofluorescence assay, we were able to detect M1 and NP proteins in mouse lungs at several time-points after the virus application (Fig 3). This finding motivated us to examine how avian viruses interact with the mammalian host immune system before they are adapted to the new host, mainly whether such viruses can trigger production of specific antibodies in the mammalian host, which are able to inhibit the replication of avian viruses.

Detection of virus-specific antibodies in sera of mice exposed to $A / D u c k$

The level of virus-specific antibodies measured by ELISA binding test was examined after a single infection of mice 
(a)

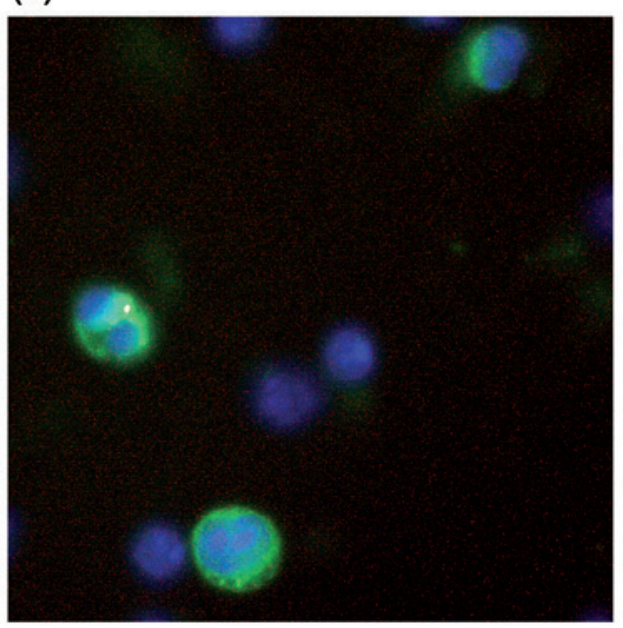

(b)

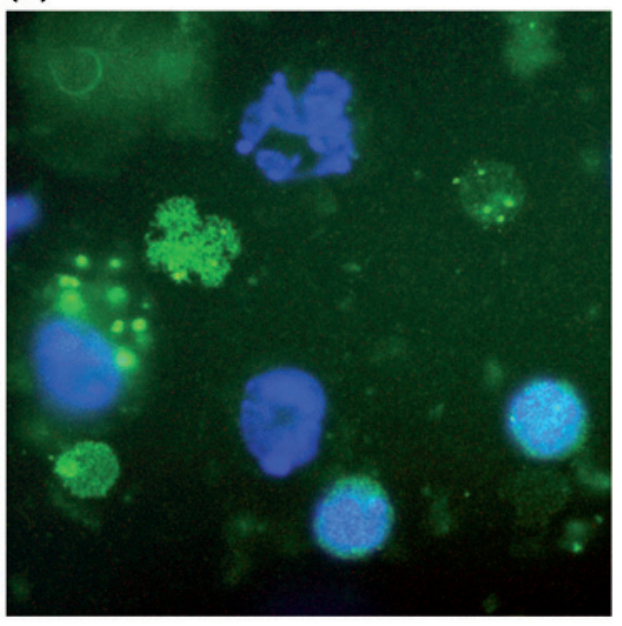

Fig. 3

Detection of viral NP and M1 by immunofluorescence

IAV NP (a) and membrane protein (b) in mouse lung cells was detected 4 days after the application of influenza virus A/Duck (H4N6) with MAb specific to NP (a) or M1 protein (b) of IAV and anti-mouse IgG antibody conjugated to FITC.

with different doses of A/Duck virus (640, 64, 6.4 and 0.64 $\mathrm{PFU} /$ mouse) and then after the second intranasal application of equal dose of A/Duck virus to mice in each experimental group (64 PFU/mouse, $\mathrm{n}=3$ /group). A marked titer of virus-specific antibodies was detected in mice already after a single application of a low virus dose (0.64 PFU) and it increased when a higher dose was used (Table 1). After the second exposure of mice to A/Duck (64 PFU/mouse), the level of specific antiviral antibodies increased significantly in all groups of mice. However, no marked titer of virusspecific antibodies was detected in group of mice exposed to UV-inactivated virus.

The titers of antibodies specific to IAV proteins were evaluated by Western blot analysis using various dilutions of immune sera obtained from mice after their exposure to A/
Duck virus. Western blot analysis of virus-specific antibodies showed that antibodies estimated by ELISA represented not only those targeted to the surface antigen, HA, but also antibodies specific to internal antigens, NP and M1 (Fig. 4, Table 2), similarly as in the case of fully replicating human IAV A/Miss.

\section{Detection of VN antibodies in sera of mice exposed to} A/Duck virus

We examined, whether the avian IAV with above-described limited replication in mouse lungs is able to induce biologically active antibodies neutralizing the virus. No VN antibodies were detectable after the application of the first dose of the infectious virus, regardless of the amount

Table 1. Titer of virus-specific and VN antibodies induced in mice after intranasal application of A/Duck virus

\begin{tabular}{|c|c|c|c|c|c|}
\hline \multicolumn{2}{|c|}{$\begin{array}{l}\text { Virus dose } \\
\quad(P F U)\end{array}$} & \multicolumn{2}{|c|}{$\begin{array}{c}\text { ELISA } \\
\text { Virus-specific antibodies }\end{array}$} & \multicolumn{2}{|c|}{$\begin{array}{c}\text { Micro-VN test } \\
\text { Virus-neutralizing antibodies }\end{array}$} \\
\hline $1^{\text {st }}$ & $2^{\text {nd }}$ & $1^{\text {st }}$ dose & $2^{\text {nd }}$ dose & $1^{\text {st }}$ dose & $2^{\text {nd }}$ dose \\
\hline 640 & 64 & 21,100 & 80,700 & $<200$ & 1,600 \\
\hline 64 & 64 & 30,000 & 122,100 & $<200$ & 3,200 \\
\hline 6.4 & 64 & 8,800 & 65,200 & $<200$ & 1,600 \\
\hline 0.64 & 64 & 6,000 & 96,800 & ND & 3,200 \\
\hline $64^{\mathrm{UV}}$ & $64^{\mathrm{UV}}$ & $<100$ & $<400$ & $<200$ & $<200$ \\
\hline
\end{tabular}

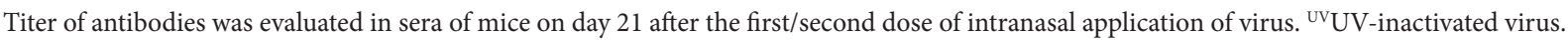




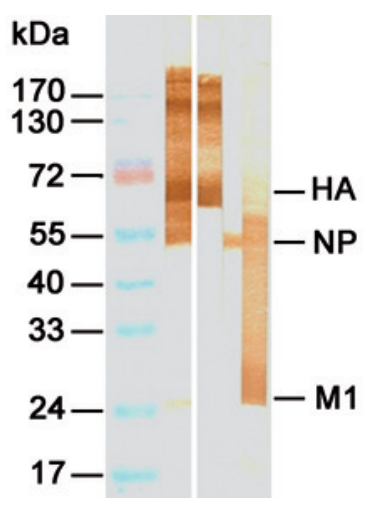

Fig. 4

Western blot analysis of antibodies in mouse sera Western blot analysis of antibodies in sera of mice inoculated with two doses of A/Duck virus: sample-containing serum (dilution 1:500) was incubated with nitrocellulose membrane, to which were blotted electrophoretically separated viral proteins of influenza A virus A/Duck (H4 subtype). Signal was detected using HRP-conjugated anti-mouse antibody and diaminobenzidine substrate.

of applied virus (Table 1). After the second application of A/Duck virus, however, the titer of $\mathrm{VN}$ antibodies reaching 1600-3200 was detected. In contrast, no single or double application of UV-inactivated virus led to the induction of measurable levels of $\mathrm{VN}$ antibodies.

Our results indicate that the non-adapted avian IAV strain A/Duck induces a full specific antibody response in mice. Although no infectious virus was proven in lungs of mice exposed to this virus, it is able to start its replication and virus protein synthesis.

Cytokine mRNA expression and cytokine level in lungs of mice infected with A/Duck virus

Finally, for a more complex image of the immune response of the host induced by the infection with non-adapted IAV of $\mathrm{H} 4$ subtype, we analyzed the cytokine profile in lung cell homogenates of infected mice. We focused on the expression of proinflammatory (IFN- $\gamma$-inducible protein 10 (IP-10), IL-6, TNF-a, IL-1) and anti-inflammatory (IL-13) cytokine-specific mRNAs as well as the direct estimation of cytokine levels present in lung cell homogenates after the infection with A/Duck virus. These results were compared with cytokine profile in lungs of mice infected with fully replicating human mouse-adapted A/Miss virus of $\mathrm{H} 3$ subtype characterized before (Fislová et al., 2009). The expression of cytokines was examined by quantitative real-time PCR $48 \mathrm{~h}$ after infection. The constantly expressed $\beta$-actin was used as an endogenous control. The infection with mouseadapted A/Miss virus caused increased mRNA expression of all examined cytokines except IL-13 (<0.03\%). Most profound was the expression of IP-10 (181\%), then TNF- $\alpha$ (8.78\%), IL-6 (1.44\%), and IL-1 (1.2\%) (Table 3). On the other hand, increased cytokine mRNA expression in mouse lungs $48 \mathrm{~h}$ after the application of non-adapted infectious virus A/Duck was apparent only in the case of IP-10 (3.98\%) and TNF- $\alpha(1.67 \%)$. The increase of mRNA expression of all other examined cytokines (IL-1, IL-6, IL-13) was only

Table 2. Titer of antigen-specific antibodies induced in mice after infection with A/Duck virus as determined by Western blot

\begin{tabular}{|c|c|c|c|c|c|c|c|}
\hline \multicolumn{2}{|c|}{$\begin{array}{c}\text { Virus dose } \\
\text { (PFU/mouse) }\end{array}$} & \multicolumn{2}{|c|}{$\begin{array}{c}\text { Titer of } \\
\text { anti-HA antibodies }\end{array}$} & \multicolumn{2}{|c|}{$\begin{array}{c}\text { Titer of } \\
\text { anti-NP antibodies }\end{array}$} & \multicolumn{2}{|c|}{$\begin{array}{c}\text { Titer of } \\
\text { anti-M1 antibodies }\end{array}$} \\
\hline $1^{\text {st }}$ & $2^{\text {nd }}$ & $1^{\text {st }}$ dose & $2^{\text {nd }}$ dose & $1^{\text {st }}$ dose & $2^{\text {nd }}$ dose & $1^{\text {st }}$ dose & $2^{\text {nd }}$ dose \\
\hline 640 & 64 & 16,000 & 128,000 & 2,000 & 32,000 & $<500$ & 8,000 \\
\hline 64 & 64 & 16,000 & 32,000 & 1,000 & 16,000 & $<500$ & 1,000 \\
\hline 6.4 & 64 & 4,000 & 128,000 & 1,000 & 32,000 & $<500$ & $<500$ \\
\hline 0.64 & 64 & 4,000 & 256,000 & $<500$ & 32,000 & $<500$ & 8,000 \\
\hline $64^{\mathrm{UV}}$ & $64^{\mathrm{UV}}$ & $<100$ & $<100$ & $<100$ & $<100$ & $<100$ & $<100$ \\
\hline
\end{tabular}

Titer of antibodies was evaluated in sera of mice on day 21 after the first/second dose of intranasal application of A/Duck virus. ${ }^{\text {UV}} \mathrm{UV}$-inactivated virus.

Table 3. Levels of cytokine mRNA in mouse lungs after intranasal application of IAV A/Duck and A/Miss

\begin{tabular}{lcccc}
\hline \multirow{2}{*}{ Virus } & \multicolumn{4}{c}{ Expression increase of immune mediator (\%) } \\
\cline { 2 - 5 } & TNF- $\alpha$ & IL-1 & IL-6 & IL-13 \\
\hline A/Miss & 8.78 & 1.2 & 1.44 & $<0.03$ \\
A/Duck & 1.67 & $<0.16$ & $<0.16$ & $<0.16$ \\
\hline
\end{tabular}

Expression of $\beta$-actin mRNA was taken as a reference. Non-infected mice were examined as a control, showing all values $<0.3 \%$. Mice after application of UV-inactivated virus A/Miss or A/Duck showed negligible increase $(<0.5 \%)$. 
negligible, comparable to the levels detected after intranasal application of UV-inactivated viruses A/Miss and A/Duck and in lungs of non-infected mice. At the same time, the cytokine concentration in lung cell homogenates after infection of mice with A/Miss and A/Duck viruses estimated by ELISA showed that higher values of IL-6 (52.07 pg/100 $\mu \mathrm{l})$ and TNF- $\alpha(21.54 \mathrm{pg} / 100 \mu \mathrm{l})$ are present in lungs of A/Missinfected mice, while only negligible levels were detected in lungs of mice exposed to A/Duck virus. No significant changes in IL-1 and IL-13 concentrations in mouse lungs have been detected after the exposure of animals to A/Miss or A/Duck virus.

These results correlate with our hypothesis that nonadapted H4 IAV has only limited ability to replicate in non-natural host and cannot start productive infection. It is therefore not able to induce an inflammatory response comparable to fully replicating mouse-adapted virus A/Miss.

\section{Discussion}

Avian influenza A viruses, endemic in aquatic birds, are known to be potentially infectious for humans and other mammals even without adaptation (Driskell et al., 2012). Acquirement of adaptation changes in the genome of such avian IAV could lead to a pandemic danger for humans. It was shown that wild bird IAVs can directly infect mammals with minimal or no clinical symptoms. Yet different magnitude of seroconversion makes the monitoring of the mammalian infections caused by avian IAV difficult (Yamazaki et al., 2009; Yang et al., 2012; Reed et al., 2014; Wang et al., 2014; Yang et al., 2014; Huang et al., 2015). On the other hand, the risk of avian and human IAV reassortants formation in susceptible wild and domestic mammalian species attracted the attention of many investigators. The host immune response to IAVs results from the mutual cooperation of various virus and host factors and can also determine the spread of newly emerged IAVs of avian origin among humans. Here we analyzed the antibody response induced in mice after their exposure to non-pathogenic IAV isolated from wild ducks in the year 1956.

Our results show that the exposure of mice to infectious non-adapted avian IAV was sufficient for induction of virusspecific antibodies, despite the inability of this virus to fully replicate in the mammalian host. As we showed here, the level of these antibodies increased markedly after the second exposure to virus, when also $\mathrm{VN}$-antibodies were detected. However, as the UV-inactivated virus did not induce the relevant antibody response, we suggest that the replication of virus-specific mRNA and genome RNA as well as the synthesis of particular viral proteins was required for virusspecific antibody response. Many molecular mechanisms are activated after the virus attachment and entry into the susceptible cells of the respiratory tract. At the beginning, the mechanisms of native immune response are activated, which may then consequently contribute to the course and severity of the disease (Julkunen et al., 2001; Sládková and Kostolanský, 2006; Maines et al., 2008). Among these mechanisms are included those stimulating the expression of immune mediators. Cytokine profile mirrors the inflammatory reaction of the organism to the virus (van Reeth, 2000; Julkunen et al., 2001; Kaiser et al., 2001; Kaufmann et al., 2001; Dienz et al., 2012,). "Early cytokines" are the first to be produced at the site of infection. Later, mainly proinflammatory (particularly IL-6, IL-1, IFN- $\gamma$, and TNF- $\alpha$ ) but also antiviral (IFN- $\alpha / \beta)$, as well as other cytokines are produced (e.g. RANTES, MIP$1 \alpha / \beta$, MCP-1, MCP-3 and IP-10) (Julkunen et al., 2000; Xie et al., 2014; Zhao et al., 2014; Shen et al., 2015).

We monitored the expression of mRNA specific to TNF- $\alpha$, IFN- $\beta$, IL-1, IL-2, IL-4, IL-6, IL-10, IL-11, IL-13, IP-10, iNOS, but only pro-inflammatory cytokines IL-1, IL-6, TNF- $\alpha$ and interferon IP-10 presented reasonable changes in mouse lungs after a sublethal dose of mouse-adapted influenza virus $\mathrm{A} / \mathrm{Miss}\left(0.1 \mathrm{LD}_{50}\right)$ of medium virulence. These cytokines represented the markers of pro-inflammatory response of mice to the IAV infection. We compared them with the profile of cytokine-specific mRNA induced in mouse lungs after exposure to non-adapted A/Duck virus. Though no clinical symptoms of the disease were observed after the exposure of mice to A/Duck virus, we recorded increased expression of TNF- $\alpha$ and IP-10 in their lungs in comparison to the negative control groups of mice (non-immunized or exposed to UV-inactivated virus). It was, however, significantly lower in comparison to the expression level of cytokine mRNA induced by sub-lethal dose of fully replicating virus A/Miss. On the other hand, only negligible increase in expression of interleukin IL-6, IL-1 and IL-13 mRNA was observed in lungs of mice exposed to A/Duck virus in contrast to mice exposed to fully replicating A/Miss virus. Notably, protein concentrations of cytokines in lungs of mice exposed to A/ Duck virus did not differ from those of non-infected mice or from those of mice, to which UV-inactivated A/Duck or A/Miss virus was applied.

Despite the mild cytokine response in lungs of mice infected with A/Duck virus, the specific antibody response with an antibody subpopulation neutralizing the virus was elicited. Abortive infection of A/Duck virus of H4N6 subtypes was shown in our experiments, as we were not able to detect infectious virus in mouse lungs. We proved the presence of virus-specific mRNA and de novo synthesized proteins, particularly NP and M1, suggesting that virus replication and protein synthesis started after the infection, but were interrupted. It is, therefore, likely that the block of the replication cycle is at the step of viral assembly and it could be caused by low protein synthesis or by the incompatibility of the host protein transport machinery required to produce 
complete virion, which is in correlation with studies by Ioannidis et al. (2012).

Based on our results we can conclude that non-adapted A/ Duck virus with limited replication in mouse lungs is able to start mild inflammatory response in mice and that it is able to induce virus-specific antibodies. These antibodies have a biological activity and neutralize the virus infection. Such antibodies could protect the organism from a subsequent more dangerous virus of the same subtype, or can milden the course of infection caused by it. Nevertheless, the VN antibody response could also contribute to the immune resistance of individuals exposed to newly emerged avian viruses in human population and consequently can influence the spread of these viruses.

Acknowledgements. The authors of this work wish to thank Mrs. M. Némethová and Mrs. M. Mišovičová for their excellent technical assistance. This work was supported by the grants VEGA 2/0176/12, VEGA 2/0146/15, VEGA 2/0100/13, VEGA-2/0153/14, VEGA 2/0152/14 from the Scientific Grant Agency of Ministry of Education of Slovak Republic and Slovak Academy of Sciences and by grants APVV-0250-10 and DO7RP-0025-10 from the Slovak Research and Development Agency.

\section{References}

Dienz O, Rud JG, Eaton SM, Lanthier PA, Burg E, Drew A, Bunn J, Suratt BT, Haynes L, Rincon M (2012): Essential role of IL-6 in protection against H1N1 influenza virus by promoting neutrophil survival in the lung. Mucosal Immunol. 5, 258-266. http://dx.doi.org/10.1038/mi.2012.2

Driskell EA, Pickens JA, Humberd-Smith J, Gordy JT, Bradley KC, Steinhauer DA, Berghaus RD, Stallknecht DE, Howerth EW, Tompkins SM (2012): Low pathogenic avian influenza isolates from wild birds replicate and transmit via contact in ferrets without prior adaptation. PLoS One 7(6): e38067. http://dx.doi.org/10.1371/journal. pone. 0038067

Du Ry van Beest Holle M, Meijer A, Koopmans M, de Jager CM (2005): Human-to-human transmission of avian influenza A/H7N7, The Netherlands, 2003. Euro Surveill. $10,264-268$.

Fislová T, Gocník M, Sládková T, Ďurmanová V, Rajčáni J, Varečková E, Mucha V, Kostolanský F (2009): Multiorgan distribution of human influenza A virus strains observed in mouse model. Arch. Virol. 154, 409-419. http://dx.doi. org/10.1007/s00705-009-0318-8

Fislová T, Thomas B, Graef KM, Fodor EF (2010): Association of the influenza virus RNA polymerase subunit PB2 with the host chaperonin CCT. J. Virol. 84, 8691-8699. http:// dx.doi.org/10.1128/JVI.00813-10

Freidl GS, Meijer A, de Bruin E, de Nardi M, Munoz O, Capua I, Breed AC, Harris K, Hill A, Kosmider R, Banks J, von Dobschuetz S, Stark K, Wieland B, Stevens K,van der Werf S, Enouf V, van der Meulen K, Van Reeth K, Dauphin G,
Koopmans M, FLURISK Consortium (2014): Influenza at the animal-human interface: a review of the literature for virological evidence of human infection with swine or avian influenza viruses other than $\mathrm{A}(\mathrm{H} 5 \mathrm{~N} 1)$. Euro Surveill. 19(18), pii=20793. http://dx.doi.org/10.2807/15607917.es2014.19.18.20793

Gocník M, Fislová T, Mucha V, Sládková T, Russ G, Kostolansky F, Varecková E. (2008): Antibodies induced by the HA2 glycopolypeptide of influenza virus haemagglutinin improve recovery from influenza A virus infection. J. Gen. Virol. 89, 958-967. http://dx.doi.org/10.1099/ vir.0.83524-0

Huang SY, Yang JR, Lin YJ, Yang CH, Cheng MC, Liu MT, Wu HS, Chang FY (2015): Serological comparison of antibodies to avian influenza viruses, subtypes H5N2, H6N1, H7N3 and H7N9 between poultry workers and non-poultry workers in Taiwan in 2012. Epidemiol. Infect. 12, 1-10. http://dx.doi.org/10.1017/s0950268815000394

Ioannidis L, Verity EE, Crawford S, Rockman SP, Brown LE (2012): Abortive replication of influenza virus in mouse dendritic cells. J. Virol. 86, 5922-5925. http://dx.doi.org/10.1128/ JVI.07060-11

Janulíková J, Stropkovská A, Bobišová Z, Košík I, Mucha V, Kostolansky F, Varečková E (2015): Virus-neutralizing antibody response of mice to consecutive infection with human and avian influenza A viruses. Acta Virol. 59, 166-173. http://dx.doi.org/10.4149/av $2015 \quad 02 \quad 166$

Joseph T, McAuliffe J, Lu B, Jin H, Kemble G, Subbarao K (2007): Evaluation of replication and pathogenicity of avian influenza A H7 subtype viruses in a mouse model. J. Virol. 81, 10558-10566. http://dx.doi.org/10.1128/JVI.00970-07

Julkunen I, Melén K, Nyqvist M, Pirhonen J, Sareneva T, Matikainen S (2000): Inflammatory responses in influenza A virus infection. Vaccine 19, 32-37. http://dx.doi.org/10.1016/ $\underline{\text { S0264-410X(00)00275-9 }}$

Julkunen I, Sareneva T, Pirhonen J, Ronni T, Melén K, Matikainen S (2001): Molecular pathogenesis of influenza A virus infection and virus-induced regulation of cytokine gene expression. Cytokine Growth Factor Rev. 12, 171-180. http://dx.doi.org/10.1016/S1359-6101(00)00026-5

Kaiser L, Fritz RS, Straus SE, Gubareva L, Hayden FG (2001): Symptom pathogenesis during acute influenza: interleukin-6 and other cytokine responses. J. Med. Virol. 64, 262-268. http://dx.doi.org/10.1002/jmv.1045

Kang HM, Choi JG, Kim KI, Park HY, Park CK, Lee Y (2013): Genetic and antigenic characteristics of $\mathrm{H} 4$ subtype avian influenza viruses in Korea and their pathogenicity in quails, domestic ducks and mice. J. Gen. Virol. 94, 30-39. http://dx.doi.org/10.1099/vir.0.046581-0

Karasin AI, Brown IH, Carman S, Olsen CW (2000): Isolation and characterization of H4N6 avian influenza viruses from pigs with pneumonia in Canada. J. Virol. 74, 9322-9327. http://dx.doi.org/10.1128/JVI.74.19.9322-9327.2000

Kaufmann A, Salentin R, Mayer RG, Bussfeld D, Pauligk C, Fesq H, Hofmann P, Nain M, Gemsa D, Sprenger H (2001): Defense against influenza A virus infection: essential role of the chemokine system. Immunobiology 204, 603-613. http://dx.doi.org/10.1078/0171-2985-00099 
Klenk HD, Garten W, Matrosovitch M (2013): Pathogenesis. In Webster RG, Monto AS, Braciale TJ, Lamb RA (Ed.): Textbook of Influenza. Chapter 10. John Wiley and Sons, Ltd., pp. 157-171. http://dx.doi.org/10.1002/9781118636817. $\underline{\operatorname{ch} 10}$

König R, Stertz S, Zhou Y, Inoue A, Hoffmann HH, Bhattacharyya S, Alamares JG, Tscherne DM, Ortigoza MB, Liang Y, Gao Q, Andrews SE, Bandyopadhyay S, De Jesus P, Tu BP, Pache L, Shih C, Orth A, Bonamy G, Miraglia L, Ideker T, García-Sastre A, Young JA, Palese P, Shaw ML, Chanda SK (2010): Human host factors required for influenza virus replication. Nature. 463, 813-817. http://dx.doi. org/10.1038/nature08699

Koopmans M, Wilbrink B, Conyn M, Natrop G, van der Nat H, Vennema H, Meijer A, van Steenbergen J, Fouchier R, Osterhaus A, Bosman A (2004): Transmission of H7N7 avian influenza A virus to human beings during a large outbreak in commercial poultry farms in the Netherlands. Lancet 363, 587-593. http://dx.doi.org/10.1016/S01406736(04)15589-X

Korth M, Kash JC, Baskin CR, Katze MG (2006): Insights into influenza virus-host interactions through global gene expression profiling: cell culture systems to animal models. In Kawaoka Y, Caister (Ed.): Influenza Virology. Ac. Press, Norfolk, England, pp.341-360.

Kosik I, Holly J, Russ G (2013): PB1-F2 expedition from the whole protein through the domain to aa residue function. Acta Virol. 57, 138-148. http://dx.doi.org/10.4149/ av $2013 \quad 02 \quad 138$

Li KS, Guan Y, Wang J, Smith GJ, Xu KM, Duan L, Rahardjo AP,Puthavathana P, Buranathai C, Nguyen TD, Estoepangestie AT, Chaisingh A, Auewarakul P, Long HT, Hanh NT, Webby RJ, Poon LL, Chen H, Shortridge KF, Yuen KY, Webster RG, Peiris JS (2004): Genesis of a highly pathogenic and potentially pandemicH5N1 influenza virus in eastern Asia. Nature 430, 209-213. http://dx.doi. org/10.1038/nature02746

Liu M, He S, Walker D, Zhou N, Perez DR, Mo B, Li F, Huang X, Webster RG, Webby RJ (2003): The influenza virus gene pool in a poultry market in south central China. Virology 305, 267-275. http://dx.doi.org/10.1006/viro.2002.1762

Liu J, Xiao H, Wu Y, Liu D, Qi X, Shi Y, Gao GF (2014): H7N9: a low pathogenic avian influenza A virus infecting humans. Curr. Opin. Virol. 5, 91-97. http://dx.doi.org/10.1016/j. coviro.2014.03.001

Maines TR, Szretter KJ, Perrone L, Belser JA, Bright RA, Zeng H, Tumpey TM, Katz JM (2008): Pathogenesis of emerging avian influenza viruses in mammals and the host innate immune response. Immunol. Rev. 225, 68-84. http:// dx.doi.org/10.1111/j.1600-065X.2008.00690.x

Neumann G, Kawaoka Y (2015): Transmission of influenza A viruses. Virology 479, 234-246. http://dx.doi.org/10.1016/j. virol.2015.03.009

Neumann G, Chen H, Gao GF, Shu Y, Kawaoka Y (2010): H5N1 influenza viruses: outbreaks and biological properties. Cell Res. 20, 51-61. http://dx.doi.org/10.1038/cr.2009.124

Peiris J, Guan Y, Markwell D, Ghose P, Webster R, Shortridge $\mathrm{K}$ (2001): Cocirculation of avian H9N2 and contemporary
"human"H3N2 influenza A viruses in pigs in southeastern China: potential for genetic reassortment? J. Virol. 75, 9679-9686. http://dx.doi.org/10.1128/JVI.75.20.9679$\underline{9686.2001}$

Reed C, Bruden D, Byrd KK, Veguilla V, Bruce M, Hurlburt D, Wang D, Holiday C, Hancock K, Ortiz JR, Klejka J, Katz JM, Uyeki TM (2014): Characterizing wild bird contact and seropositivity to highly pathogenic avian influenza A (H5N1) virus in Alaskan residents. Influenza Other Respir. Viruses 8, 516-523. http://dx.doi.org/10.1111/ $\underline{\text { irv. } 12253}$

Resa-Infante P, Gabriel G (2013): The nuclear import machinery is a determinant of influenza virus host adaptation. Bioessays 35, 23-27. http://dx.doi.org/10.1002/bies.201200138

Resa-Infante P, Thieme R, Ernst T, Arck PC, Ittrich H, Reimer R, Gabriel G (2014): Importin- $\alpha 7$ is required for enhanced influenza A virus replication in the alveolar epithelium and severe lung damage in mice. J. Virol. 88, 8166-8179. http://dx.doi.org/10.1128/JVI.00270-14

Russ G, Styk B, Poláková K, Varečková E (1976): Competitiveinhibition radioimmunoassay for influenza virus envelope antigens. Acta Virol. 20, 460-465.

Schrauwen EJ, Fouchier RA (2014): Host adaptation and transmission of influenza A viruses in mammals. Emerg. Microbes Infect. 3, e9. http://dx.doi.org/10.1038/emi.2014.9

Shen P, Fillatreau S (2015): Antibody-independent functions of B cells: a focus on cytokines. Nat. Rev. Immunol. 15, 441-451. http://dx.doi.org/10.1038/nri3857

Sládková T, Kostolanský F (2006): The role of cytokines in the immune response to influenza A virus infection. Acta Virol. 50, 151-162.

Stropkovská A, Mucha V, Fislová T, Gocník M, Kostolanský F, Varečková E (2009): Broadly cross-reactive monoclonal antibodies against $\mathrm{HA} 2$ glycopeptide of influenza A virus hemagglutinin of $\mathrm{H} 3$ subtype reduce replication of influenza A viruses of human and avian origin. Acta Virol. 53, 15-20. http://dx.doi.org/10.4149/av_2009_01_15

Subbarao K, Klimov A, Katz J, Regnery H, Lim W, Hall H, Perdue M, Swayne D, Bender C, Huang J, Hemphill M, Row T, Shaw M, Xu X, Fukuda K, Cox NJ (1998): Characterization of an avian influenza $\mathrm{A}$ (H5N1) virus isolated from a child with a fatal respiratory illness. Science 279, 393-396. http://dx.doi.org/10.1126/science.279.5349.393

Subbarao K, Katz J (2000): Avian influenza viruses infecting humans. Cell Mol. Life Sci. 57, 1770-1784. http://dx.doi. org/10.1007/PL00000657

Tkáčová M, Varečková E (1996): A sensitive one-step immunocapture EIA for rapid diagnosis of influenza A. J. Virol. Methods 60, 65-71. http://dx.doi.org/10.1016/01660934(96)02046-0

Tscherne DM, Garcia-Sastre A (2011): Virulence determinants of pandemic influenza viruses. J. Clin. Invest, 121, 6-13. http://dx.doi.org/10.1172/JCI44947

Van Reeth K (2000): Cytokines in the pathogenesis of influenza, Vet Microbiol. 74, 109-116. http://dx.doi.org/10.1016/ S0378-1135(00)00171-1

Varečková E, Betáková T, Mucha V, Soláriková L, Kostolanský F, Waris M, Russ G (1995): Preparation of monoclonal 
antibodies for the diagnosis of influenza A infection using different immunization protocols. J. Immunol. Methods. 180, 107-116. http://dx.doi.org/10.1016/00221759(94)00307-I

Varečková E, Wharton S, Mucha V, Gocník M, Kostolanský F (2003): A monoclonal antibody specific to the HA2 glycoprotein of influenza A virus hemagglutinin that inhibits its fusion activity reduces replication of the virus. Acta Virol. 49, 229-236.

Varečková E, Blaškovičová H, Gocník M, Mikas J, Adamčáková J, Fislová, T, Kostolanský F, Mucha V (2006): Evaluation of clinical specimens for influenza A virus positivity using various diagnostic methods. Acta Virol. 50, 181-186.

Wang C, Yu H, Horby PW, Cao B, Wu P, Yang S, Gao H, Li H, Tsang TK, Liao Q, Gao Z, Ip DK, Jia H, Jiang H, Liu B, Ni MY, Dai X, Liu F, Van Kinh N, Liem NT, Hien TT, Li Y, Yang J, Wu JT, Zheng Y, Leung GM, Farrar JJ, Cowling BJ, Uyeki TM, Li L. (2014): Comparison of patients hospitalized with influenza A subtypes $\mathrm{H} 7 \mathrm{~N} 9, \mathrm{H} 5 \mathrm{~N} 1$, and 2009 pandemic H1N1. Clin. Infect. Dis. 58, 1095-1103. http://dx.doi.org/10.1093/cid/ciu053

Weber TP, Stilianakis NI (2007): Ecologic immunology of avian Influenza (H5N1) in migratory birds. Emerg. Infect. Dis. 13, 1139-1143. http://dx.doi.org/10.3201/eid1308.070319

Wong SS, Yuen KY (2006): Avian influenza infections in humans. Chest. 129, 156-168. http://dx.doi.org/10.1378/ chest.129.1.156
Xie J, Zhang S, Hu Y, Li D, Cui J, Xue J, Zhang G, Khachigian LM, Wong J, Sun L, Wang M (2014): Regulatory roles of c-jun in H5N1 influenza virus replication and host inflammation. Biochim. Biophys. Acta 1842, 2479-2488. http:// dx.doi.org/10.1016/j.bbadis.2014.04.017

Yamazaki Y, Doy M, Okabe N, Yasui Y, Nakashima K, Fujieda T, Yamato S, Kawata Y, Ogata T (2009): Serological survey of avian H5N2-subtype influenza virus infections in human populations. Arch. Virol.154, 421-427. http://dx.doi. org/10.1007/s00705-009-0319-7

Yang P, Ma C, Shi W, Cui S, Lu G, Peng X, Zhang D, Liu Y, Liang H, Zhang Y, Zhang L, Seale H, Wang Q (2012): A Serological Survey of Antibodies to H5, H7 and H9 Avian Influenza Viruses amongst the Duck-Related Workers in Beijing, China. PLoS ONE 7, e50770. http://dx.doi.org/10.1371/ journal.pone. 0050770

Yang S, Chen Y, Cui D, Yao H, Lou J, Huo Z, Xie G, Yu F, Zheng S, Yang Y, Zhu Y, Lu X, Liu X, Lau SY, Chan JF, To KK, Yuen KY, Chen H, Li L (2014): Avian-origin influenza A(H7N9) infection in influenza A(H7N9)-affected areas of China: a serological study. J. Infect. Dis. 209, 265-269. http://dx.doi.org/10.1093/infdis/jit430

Zhao G, Liu C, Kou Z, Gao T, Pan T, Wu X, Yu H, Guo Y, Zeng Y, Du L, Jiang S, Sun S, Zhou Y (2014): Differences in the pathogenicity and inflammatory responses induced by avian influenza $\mathrm{A} / \mathrm{H} 7 \mathrm{~N} 9$ virus infection in $\mathrm{BALB} / \mathrm{c}$ and C57BL/6 mouse models. PLoS One. 9, e92987. http:// dx.doi.org/10.1371/journal.pone.0092987 